\title{
Perceived Influence of Opposition Political Campaign Materials on Voters
}

\author{
Syed Arabi Idid ${ }^{1}$, and Rizwanah Souket ${ }^{1, *}$ \\ ${ }^{1}$ Department of Communication, International Islamic University, Malaysia
}

\begin{abstract}
This article focuses on how political attitudes of voters are shaped and affected during election campaigns. The study is constructed on the third person effect paradigm that posits that negative messages will have a greater impact not on 'me' or 'you' but on 'them'. Concurrently, perceived positive messages will have a greater influence on themselves compared to others, often referred to as the first-person effect or reversethird person effect (Duck, Terry \& Hogg, 1995; Perloff 1999). The present study was undertaken to understand how political communication messages can have a positive effect on own party supporters while the same message can be perceived to be biased and partisan to opposing party supporters. The current study is grounded on the research done by Idid \& Souket (2014) that investigated the effects of Malaysia's largest political party, Barisan Nasional (BN) political communication literature on two Malaysian voter groups (BN voters and opposition voters), one of which regarded the message as partisan and the other as congenial. The present study attempts to investigate the effects of each of the opposition party political communication literature on two Malaysian voter groups (BN party supporters and the particular opposition party supporter).
\end{abstract}

\section{Introduction}

The Third Person Effect theory associated with Phillips Davison [1] postulated that audience members would deny media's direct effect on themselves but would perceive media's effect on others [1,2 \& 3]. Several studies have focussed on voter perception and behaviour using the third person paradigm $[4,5 \& 6]$. It can be said that the classic third person effects are more pronounced when media or message content is perceived to be negative on the respondents. On the other hand, the third person effect can be reversed, called the first-person effect, when the desired message is intended to be positive on the respondents $[7 \& 8]$. The third-person effect theory simply states that a message, perceived to be not welcome, can exert a greater influence on others than on the self. Thus, the message will have the least impact on 'me' (first person), you (members closest to the first person) and the greatest impact on them (others, the third person). Given the premise, the present study attempts to investigate the third person effect ideology among the Malaysian voters in the country's political settings.

\footnotetext{
* Corresponding author: rizwanahsouket@gmail.com
} 
The Barisan Nasional (BN), the country's dominant party, has captured two-third majority seats in parliament since Malaysia got its independence from the British in 1957. However during the 2008 general election, BN lost its two-thirds majority parliamentary seats by winning140 seats while the opposition (Pakatan Rakyat) won 82 seats. Likewise, in the 2013 general elections, BN again lost its two third majority parliamentary seats to the opposition group. This time BN won 133 seats while the opposition party (Pakatan Rakyat) won 89 seats. This raises a concern over the uprising of a more well-informed Malaysian voter group. With the highest voter turnout in Malaysia's history (84.4\%), all parties used their own strategies and political campaign materials (brochures, pamphlets, publications, leaflets and speeches) aimed at influencing the voters.

Based on the 2013 elections study, Idid and Souket [9] had found the BN respondents to have a 'first' person effect, indicating that the BN political communication literature had a greater positive impact on themselves (first person i.e. BN voters), their family and other BN supporters and a least or no positive influence on "them" (the opposition supporters and Undecided voters). The present study is keen to investigate further the influence of each of the separate opposition political communication literature on their respective opposition party voter (first person i.e. PAS, DAP or PKR voters), their family and other opposition party supporters and on "them" (the BN supporters and Undecided voters). By studying the campaign materials and their perceived influence, this is a reverse situation from the 2013 study.

The opposition coalition called Pakatan Rakyat consists of three parties: Parti Keadilan Rakyat (The People's Justice Party, PKR), the Democratic Action Party (DAP) and Islam Se-Malaysia Party (Pan Malaysian Islamic Party, PAS). The Parti Keadilan Nasional fused with the Malaysian People's Party in 2003 and called themselves People's Justice Party (Parti Keadilan Rakyat, PKR) advocating social-liberal values. The DAP was founded in 1965 and advocates for secular values. Its voters mostly consist of urban ethnic Chinese. The PAS an Islamic party established in 1955 advocates Islamic values and laws. Based on the third person effect hypothesis, this study attempts to investigate the views of the respective opposition party supporters on the influence of their own party campaign materials on themselves, their family and their own party friends. Likewise the study attempts to investigate the influence of each of the opposition party political literature on the BN supporters, their family and their friends.

Idid \& Souket [9] found BN voters to have been positively influenced by the BN political campaign literature and they perceived a lesser level of influence on the opposition voters. They claim that the BN party voters are persuaded and convinced by the message projected by the $\mathrm{BN}$ political communication devices. As a result, the first person or BN respondents feel confident and comfortable when exposed to their own party communication devices and they feel that the other voters should also share a similar sentiment. In brief, the $\mathrm{BN}$ supporters view the $\mathrm{BN}$ political communication materials as a desirable message. On the other hand, when voters who had voted for the opposition parties were asked, they (Pakatan Rakyat) viewed the BN political communication message as undesirable and ultimately displayed a classic third person effect when investigating the influence of the $\mathrm{BN}$ campaign political literature on themselves, their family, and like party voters. They viewed the message to have the least effect on their own selves. Based on this finding, the current study hypothesizes the individual opposition political communication literature to have a greater level of positive influence on the respective opposition party voters and a lesser level of influence on the BN voters. Thus the respective opposition party voters (PKR, PAS, DAP) will view the message projected by their individual party as desirable and the $\mathrm{BN}$ voters would claim an undesirable effect on themselves. 


\section{The current study}

The $2013^{\text {th }}$ Malaysian elections was held on $5^{\text {th }}$ May 2013. The study was conducted in July 2013 and sought the opinion of the registered voters drawn nation-wide on several matters concerning their behaviour during the elections. About 1463 voters were selected nationwide using quota sampling from two parliamentary constituencies in each state. A total of 100 trained enumerators and 12 supervisors were involved in the data collection. A 45 minute face-to-face interviews were conducted on the respondents. The respondents were asked whether the components of Pakatan Raykat (PAS, DAP, and PKR) political campaign materials such as brochures, pamphlets, publications, and leaflets and speeches had an influence on themselves, their families, BN supporters, opposition supporters, and uncertain voters. The 'Self' category included the respondent's perception of the political party communication devices influence on themselves, their family and other similar party supporters. While the 'others' category included the influences of the political communication devices on other party supporters and uncertain voters.

\section{Findings of the study}

The total number of 1463 respondents included 695 BN supporters and 768 opposition party supporters. Out of the total opposition supporters, about $22 \%$ of the respondents were PAS supporters $(\mathrm{N}=169)$, about $48 \%$ were DAP supporters $(\mathrm{N}=365)$ and about $30 \%$ of the respondents were PKR supporters $(\mathrm{N}=234)$. The study asked supporters to state the influence of opposition party materials on own supporters which included themselves, their family, and like party supporters. They were also to state what they perceived to be the influence on voters who were not their party supporters which could be the main party voters. Likewise, BN supporters were asked to state what they perceived to be the effect of the opposition party campaign materials on themselves, their family and their own supporters. They also estimated the influence of the materials on others than BN supporters which would likely be the opposition supporters.

The study first tested the influence of PAS party campaign materials on the BN voter and on the PAS voter (table 1). It was found that the BN voters perceived that the PAS campaign materials had a moderately positive level of influence on themselves $(47 \%)$, on their family (48\%) and other BN supporters (68\%). Likewise, the BN voter perceived a positive influence of the same communication materials on the other party supporters (opposition supporters, $49 \%$ \& uncertain voters, $48 \%$ ). Hence a total of 54 percent of BN self-voter claimed to be influenced by the PAS communication materials on their self, family and like party supporters (other BN voters). To the BN supporters, the perceived influence of the PAS party materials on "the others" (besides the BN voter) was $48 \%$.

When PAS supporters were asked about how they perceived the influence of their own party materials, they admitted a greater influence on self $(97 \%)$. A total of 98 percent said the materials had an influence on their own selves, 97 percent said it had an influence on their family, and 96 percent claimed they had an influence on the party supporters. The influence of the PAS party materials on the others (beside the PAS voters like BN voters \& unlikely voters) was $68 \%$. A greater level of influence on self indicates a greater probability of a "reverse" third person effect or the 'first person' effect (table 1).

Table 1 suggests that BN supporters acknowledged the influence of PAS political materials on themselves and also on others. In a classic third person effect, the BN supporters would claim that others would be more affected by the undesirable PAS campaign materials. 
Table 1. Perceived influence of PAS Political Communication Devices on SELF and OTHERS

\begin{tabular}{|l|l|l|l|l|l|}
\hline \multirow{2}{*}{ Respondents (n=1463) } & \multicolumn{3}{|l|}{ Perceived influence (\%) } & Total & $\begin{array}{l}\text { Total } \\
\text { On }\end{array}$ \\
\cline { 2 - 6 } & $\begin{array}{l}\text { On } \\
\text { self }\end{array}$ & $\begin{array}{l}\text { On } \\
\text { family }\end{array}$ & $\begin{array}{l}\text { On like party } \\
\text { supporters }\end{array}$ & & $\begin{array}{l}\text { on } \\
\text { Other }\end{array}$ \\
\hline BN supporters $(\mathrm{n}=695)$ & 47 & 48 & 68 & 54 & 48 \\
\hline PAS supporters $(\mathrm{n}=169)$ & 98 & 97 & 96 & 97 & 68 \\
\hline
\end{tabular}

The study looked at the influence of the DAP political campaign materials on the BN voters and the DAP voters. The BN supporters indicated a slightly higher influence of the DAP political communication devices on themselves (50\%) as compared to others $(46 \%)$ (table 2). The BN voters indicated a comparatively low level of influence on self $(41 \%)$ and on family $(42 \%)$, however the voter seems to indicate the possibility of a greater level of influence on other BN supporters $(68 \%)$. The influence of the DAP political campaign materials on the DAP voter themselves indicated a greater influence on self $(95 \%)$ that comprised of self $(96 \%)$, family (94\%) and like party supporters $(95 \%)$. The influence predicted to be on others indicated a positive influence of $88 \%$, thus indicating a greater influence on the self of the voter $(95 \%)$ as compared to the perceived others $(88 \%)$. This finding confirms the 'first person' effect. The summary of the findings is presented in table 2.

Table 2: Perceived influence of DAP Political Communication Devices on SELF and OTHERS

\begin{tabular}{|c|c|c|c|c|c|}
\hline \multirow[t]{2}{*}{ Respondents (n=1463) } & \multicolumn{3}{|c|}{ Perceived influence (\%) } & \multirow{2}{*}{$\begin{array}{l}\text { Total } \\
\text { on } \\
\text { Self }\end{array}$} & \multirow{2}{*}{$\begin{array}{l}\text { Total } \\
\text { on } \\
\text { Other } \\
\end{array}$} \\
\hline & $\begin{array}{l}\text { On } \\
\text { Self }\end{array}$ & $\begin{array}{l}\text { On } \\
\text { family }\end{array}$ & $\begin{array}{l}\text { On like party } \\
\text { supporters }\end{array}$ & & \\
\hline BN supporters $(n=695)$ & 41 & 42 & 68 & 50 & 46 \\
\hline DAP supporters $(\mathrm{n}=365)$ & 96 & 94 & 95 & 95 & 88 \\
\hline
\end{tabular}

The study then investigated the influence of PKR political campaign materials on PKR and on BN supporters. This study found that the BN supporters indicated a moderately high influence of the PKR political communication devices on themselves (52\%) as compared to others (45\%) (table 3). Likewise, the BN voters indicated more confidence in the perceived influence of the PKR campaign materials on the other BN voters $(67 \%)$ than on themselves (44\%) or their close family (44\%). Congruently, the PKR voter indicated the greatest influence of the PKR materials on themselves (93\%) as compared to the others $(86 \%)$ reflecting the 'first person' effect.

Table 3: Perceived influence of PKR Political Communication Devices on SELF and OTHERS

\begin{tabular}{|c|c|c|c|c|c|}
\hline \multirow[t]{2}{*}{ Respondents (n=1463) } & \multicolumn{3}{|c|}{ Perceived influence (\%) } & \multirow{2}{*}{$\begin{array}{l}\text { Total } \\
\text { on } \\
\text { Self }\end{array}$} & \multirow{2}{*}{$\begin{array}{l}\text { Total } \\
\text { on } \\
\text { Other }\end{array}$} \\
\hline & $\begin{array}{l}\text { On } \\
\text { self }\end{array}$ & $\begin{array}{l}\text { On } \\
\text { family }\end{array}$ & $\begin{array}{l}\text { On like party } \\
\text { supporters }\end{array}$ & & \\
\hline BN supporters $(n=695)$ & 44 & 44 & 67 & 52 & 45 \\
\hline PKR supporters $(\mathrm{n}=234)$ & 94 & 92 & 93 & 93 & 86 \\
\hline
\end{tabular}

\section{Discussions}

The current study focuses on the influence of each of the individual opposition party campaign materials on Malaysian voters. The study looks into testing the vulnerability of the Malaysian voters towards the political campaign messages projected by different political parties. This study develops from the third person premise that when a message has a low likelihood or perceived negative influence (undesirable) then the third person effect is more obvious. Based on this ideology, the opposition party political message is 
projected to be looked upon as an undesirable message for the $\mathrm{BN}$ voters and supporters, thus assuming a classic third-person effect. The opposition party political messages are viewed as desirable messages on their own opposition parties and are seen to be positive thus resulting in a more first person effect or reverse-third person effect. People will acknowledge the effects of communications that are usually regarded as socially desirable, healthy or good for self [8] to be positive. Reflecting on the current study, voters receiving messages from their own parties are perceived to have a higher likability of acknowledging the influence of desirable messages and at the same time they hold the belief that others are also strongly liable to be influenced by the same messages. The findings of this study yielded an interesting result. When each of the opposition political campaign messages were tested on their own respective supporters, it was found that the respective opposition party voters displayed a high level of confidence in their own political communication message and indicated a reverse-third person effect. The findings show that the opposition voters perceive to have a higher likability and confidence in acknowledging the influence of their own party messages (desirable) and at the same time they hold the belief that the $\mathrm{BN}$ voters are also strongly liable to be influenced by the same messages. Hence positive messages are perceived to be well received by themselves and by others.

The influence of the PAS campaign materials on the PAS voters $(98 \%)$, on their family (97\%) and the perceived influence on other like opposition supporters (96\%) was comparatively higher compared to the perceived influence of the PAS campaign materials on $\mathrm{BN}$ supporters and other unlikely voters $(68 \%)$. This clearly indicated that although the message to them was positive, yet they claim the influence on others was not as high. Similar to an earlier finding [9], the BN respondents displayed an extraordinary level of confidence in meeting the messages from the opposition party. The BN voters claimed a greater influence of the PAS campaign messages with 54\% claiming the opposition party materials to have an effect on themselves but saying only 48 percent of non BN party supporters would be influenced by them. This could be associated with the selfenhancement postulate, whereby the BN voters considered the effects of the PAS messages to be positive on themselves and are liable to be influenced but it was not so with the other non BN supporters. On the other hand, the influence of the DAP campaign materials on the DAP voters indicated a high level of confidence on themselves $(96 \%)$, their family $(94 \%)$ and on other similar opposition supporters (95\%) and a lesser level of influence on their perceived other voters and unlikely voters $(88 \%)$. This finding could be attributed to the social distance between the self and distant others or the level of message desirability and subsequently the voters feel "I am smart enough to recognize the value of the message" [10]. The influence of the DAP campaign materials on the BN voter indicated again a contrary result whereby the $\mathrm{BN}$ voters indicated a greater influence on self $(50 \%)$ compared to the perceived influence on others (46\%). Finally on looking into the perceived influence of the PKR campaign materials on the PKR voter and BN voter it was found that the PKR voters displayed a strong influence of the PKR campaign materials on self (94\%), their family $(92 \%)$ and the other similar opposition party supporters $(93 \%)$. The perceived influence of the PKR campaign materials on others and unlikely voters was again a high influence of $86 \%$. This again confirms the confidence in the influence of the PKR campaign materials. The $\mathrm{BN}$ voter again displayed more confidence of being influenced by the PKR campaign materials on themselves $(52 \%)$ but claimed it would not be a factor on non BN supporters (45\%). Overall, the study has shown that people will likely accept congenial message as positive on themselves perceiving it to be in tune with their own cognitive needs [9]. Therefore, the opposition voters would claim that their campaign materials would not only have an effect on their own self, on those closest to them (family) but would also affect the BN party supporters. The earlier study [9] found that the BN supporters displayed a positive confidence on the influence of BN materials on self and on 
others. This study added that the BN supporters also found the opposition materials to have a reasonable influence on themselves more than the influence on others, denying therefore the third person effect. The opposition party materials were not seen to be unreasonable or negative to the BN supporters. Though they did not perceive the influence to be that big yet $\mathrm{BN}$ supporters perceived the opposition party materials to have lesser effects on non BN supporters.

The main objective of the study was to explore the effect of messages from the thirdperson effect perspective, but the findings have suggested a variation. The BN supporters have accepted the influence of their opponents' messages but they have rejected the influence on non BN supporters. BN supporters therefore had claimed the positive messages from the opposition parties but have rejected it to be of influence on other voters. It was also similar to the acceptance on the influence of the opposition messages on themselves and on other voters but acknowledging that they had lesser influence on other voters. In conclusion, we find each set of voters to display a positive confidence in the influence of their respective party communication messages on themselves, family and like supporters. Acceptance of a positive message does not mean acknowledging a similar level of acceptance on others. On the other hand while a negative message is accepted it does not mean that a party cannot acknowledge that the message has little influence on others.

\section{References}

1. P. Davison, Public. Opin. Quart. 47, 1 (1983)

2. B. Salwen, Commun. Res. 25, 259-285 (1998)

3. J. Brubaker, Am. Commun. J. 13, 2 (2011)

4. S. Idid, Arabi. Wok. S, Analysing political campaign effects: a test of the third person effects theory. Paper prepared for ICOMC'10, 18-20 (2010)

5. A. Banning, Journal. Mass Comm. Q. 83, 4 (2006).

6. F. Rojas, D. Shah, R. Faber, Int. J. Public. Opin. R. 8, 2 (1996).

7. J. Duck, D.J, Terry, M.A. Hogg, Eur. J. Soc. Psychol. 25, 2 (1995).

8. R, Perloff, Media. Psychol. 1, 353-378 (1999).

9. S. Idid, Arabi R. Souket, AJPOR. 1, 4 (2014)

10. J. Huh, D. DeLorme L. Reid, Journal. Mass Comm. Q. 81. 4 (2004). 